Влияние скрещивания чёрно-пёстрого скота с голштинами на качество мясной продукции

\author{
В.И. Косилов ${ }^{1}$ Ф.Г. Каюмов ${ }^{2}$ Ф.С. Амиршоев ${ }^{3}$ Р.Ф. Третьякова ${ }^{2}$, С.С. Жаймышева ${ }^{2}$ \\ ${ }^{1}$ Оренбургский государственный аграрный университет (2. Оренбург) \\ ${ }^{2}$ Федеральньй научньй иентр биологических систем и агротехнологий Российской академии наук (2. Оренбург) \\ ${ }^{3}$ Тадждикская академия сельскохозяйственных наук (2. Душанбе)
}

\begin{abstract}
Аннотация. В последние годы совершенствование чёрно-пёстрого скота проводится путём использования голштинов разной селекции. Наряду с повышением уровня молочной продуктивности отмечается улучшение и качества мясной продукции помесей. При проведении наших исследований были сформированы 4 группы молодняка по 15 животных в каждой: I - чёрно-пёстрая (бычки чистопородные), II - 1/2 голштин $\times 1 / 2$ чёрно-пёстрая (бычки), III - чёрно-пёстрая (бычки-кастраты чистопородные), IV - 1/2 голштин $\times 1 / 2$ чёрно-пёстрая (бычки-кастраты).

В ходе исследования установлено положительное влияние апробируемого варианта скрещивания на качественные показатели мясной продукции. Животные I и IV групп имели преимущество над аналогами I и III групп по индексу мясности туши на 2,45 \% и 0,98 \%, выходу мышечной ткани на 1 кг костей - на 3,17 \% и $1,31 \%$, выходу мяса высшего сорта - на $1,08 \%$ и 1,66 \%, выходу мяса первого сорта - на $1,98 \%$ и $1,09 \%$.
\end{abstract}

Ключевые слова: скотоводство, бычки, бычки-кастраты, чёрно-пёстрая порода, помеси с голштинами, выход мякоти и мышц, сортовой состав.

\title{
UDC 636.082
}

\section{Influence of crossing of Black Spotted and Holstein cattle on the quality of meat products}

\author{
Vladimir I Kosilov', Foat G Kayumov', Fayzullo S Amirshoev ${ }^{3}$, Ruzya F Tretyakova ${ }^{2}$, \\ Saule S Zhaimysheva ${ }^{2}$ \\ ${ }^{1}$ Orenburg State Agrarian University (Orenburg, Russia) \\ ${ }^{2}$ Federal Research Centre of Biological Systems and Agrotechnologies of the Russian Academy of Sciences (Orenburg, Russia) \\ ${ }^{3}$ Tajik Academy of Agricultural Sciences (Dushanbe, Republic of Tajikistan)
}

Summary. In recent years, the improvement of Black Spotted cattle has been carried out with the Holsteins of various breeding. Along with an increase in the level of milk productivity, there is an improvement in the quality of meat products from crossbreds. During our research, 4 groups of young animals were formed, 15 animals in each: I - black and white (bulls, purebred), II - 1/2 Holstein $\times 1 / 2$ black and white (bulls), III - black and white (castrated bulls, purebred ), IV - 1/2 Holstein $\times 1 / 2$ black-and-white (steer bulls). In the course of the study, a positive effect of the tested crossing option on quality indicators of meat products was established. At the same time, crossbred young animals of groups II and IV advanced over purebred animals of groups I and III by $2.45 \%$ and $0.98 \%$,according fleshing index, respectively, muscle tissue yield - per $1 \mathrm{~kg}$ of bones - by $3.17 \%$ and $1.31 \%$, the output of the highest grade meat - by $1.08 \%$ and $1.66 \%$, the output of the first grade meat - by $1.98 \%$ and $1.09 \%$.

Key words: beef cattle breeding, bulls, steers, Black Spotted breed, crossbreeds with Holstein, yield of pulp and muscles, varietal composition.

\section{Введение.}

Известно, что говядина является ценным продуктом питания, не имеющим каких-либо ограничений при приготовлении широкого ассортимента блюд (Герасимов Н.П. и др., 2010; Гильмияров Л.А. и др., 2010; Тагиров Х.Х. и др., 2010; Джуламанов К.М. и др., 2015; Макаев Ш.А. и др., 2016). 
При этом в настоящее время существенное внимание уделяется качеству мясного сырья (Кочетков А.А. и др., 2010). Этот признак имеет природную особенность, т. е. генетически детерминирован. При скрещивании скота разных пород появляется возможность вследствие проявления эффекта гетерозиса добиться не только повышения уровня мясной продуктивности, но и улучшения её качественных показателей (Есенгалиев А.К. и др., 1993; Батанов С.Д. и Корепанова Л.В., 2011; Тюлебаев С.Д., 2011; Миронова И.В. и Гильманов Д.Р., 2013; Шевхужев А.Ф. и др., 2017).

\section{Цель исследования.}

Изучение влияния скрещивания чёрно-пёстрого и голштинского скота на качественные показатели мяса помесей.

\section{Материал и методы исследования.}

Объект исследования. Чистопородные бычки и бычки-кастраты чёрно-пёстрой породы и её помеси первого поколения с голштинами немецкой селекции.

Обслуживание животных и экспериментальные исследования были выполнены в соответствии с инструкциями и рекомендациями российских нормативных актов (1987 г.; Приказ Минздрава СССР № 755 от 12.08.1977 «О мерах по дальнейшему совершенствованию организационных форм работы с использованием экспериментальных животных») и «Guide for the Care and Use of Laboratory Animals» (National Academy Press, Washington, D.C., 1996). При проведении исследований были предприняты меры, чтобы свести к минимуму страдания животных и уменьшения количества исследуемых опытных образцов.

Схема эксперимента. Исследования проводились в 2018-2019 гг. Из новорождённых бычков были сформированы 2 группы молодняка по 30 животных в каждой: I - чёрно-пёстрая (чистопородные) и II - помеси $1 / 2$ голштин×1/2 чёрно-пёстрая. По достижении 2 -месячного возраста половина бычков каждого генотипа была подвергнута кастрация открытым способом с полным удалением семенников. Таким образом, под опытом находились 4 группы молодняка: I - чёрно-пёстрая (бычки чистопородные), II - 1/2 голштин $\times 1 / 2$ чёрно-пёстрая (бычки), III - чёрно-пёстрая (бычкикастраты чистопородные), IV - 1/2 голштин×1/2 чёрно-пёстрая (бычки-кастраты).

При проведении эксперимента молодняк всех подопытных групп находился в аналогичных условиях содержания и кормления.

Для определения качественных показателей мясной продукции в 18-месячном возрасте после проведения контрольного убоя по 3 головы из каждой группы была проведена обвалка правой полутуши, жиловка её мякотной части и сортировка по колбасной классификации.

Оборудование и технологические средства. Для обвалки полутуши использовали ножи «Проотель» $\alpha$ 27/13 см (Россия), жиловки и сортировки мякотной части ножи Я2-ФИН № 15 (Россия).

Определение общей массы мякоти полутуши, мышечной ткани и массы отдельных её сортов проводили путём взвешивания на электронных весах ST-TCS-100 (Россия).

Статистическая обработка. При обработке экспериментального материала использовали методы вариационной статистики и корреляционного анализа с помощью офисного программного комплекса «Microsoft Office» с применением программы «Excel» («Microsoft», США) с обработкой данных в «Statistica 10.0» («Stat Soft Inc.», США).

\section{Результаты исследования.}

Данные, полученные при обвалке полутуши, свидетельствуют о положительном влиянии скрещивания чёрно-пёстрого скота с голштинами немецкой селекции на качество мясной продукции помесей, о чём свидетельствуют выход мякоти и соотношение тканей (табл. 1). 
Таблица 1. Выход мякоти туши молодняка подопытных групп, кг $\left(\mathbf{X} \pm \mathbf{S}_{\mathbf{x}}\right)$ / Table 1. The yield of the carcass pulp of young animals of experimental groups, $\mathbf{k g}(\mathbf{X} \pm \mathbf{S x})$

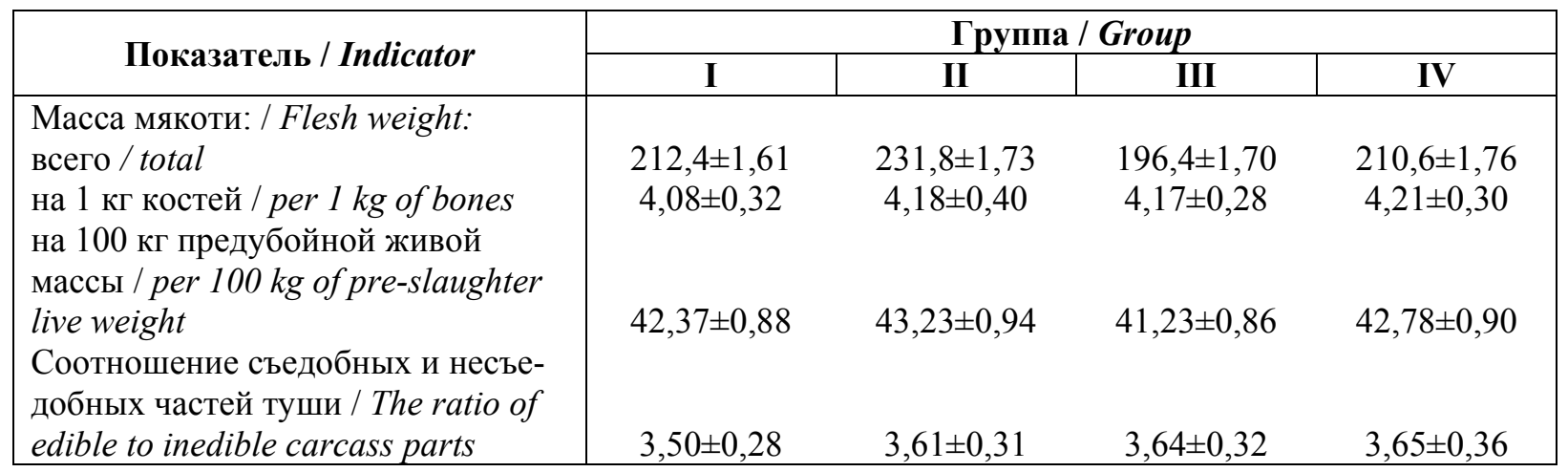

Так, бычки I группы уступали аналогам II группы по общей массе мякоти на 19,4 кг (9,13 \%, $\mathrm{P} \leq 0,001)$, а чистопородные бычки-кастраты III группы помесным сверстникам IV группы - на 14,2 кг (7,23 \%). Следовательно, у помесных бычков кастратов IV группы эффект скрещивания по абсолютной массе мякоти туши проявился в меньшей степени, чем у некастрированных бычков II группы. Максимальное содержание мякоти было выявлено в тушах у бычков I группы, которые превосходили чистопородных бычков-кастратов III группы на 16,0 кг $(8,15 \%$, P $\leq 0,001)$. У помесей II группы преимущество по данному показателю составляло 21,2 кг $(10,07 \%, \mathrm{P} \leq 0,01)$ над бычками-кастратами IV группы. Максимальный выход туши также был зафиксирован у помесей. По группе бычков это преимущество помесей составляло $2,45 \%$, бычков-кастратов - 0,98 \%. Характерно, что преимущество по величине индекса мясности было на стороне бычков-кастратов и составляло по чистопородному молодняку $2,21 \%$, по помесям $-0,72 \%$.

Достаточно информативным показателем, во многом характеризующим качество мясной продукции, является выход съедобной части туши на 100 кг предубойной живой массы. Полученные данные свидетельствуют о положительном влиянии на величину изучаемого показателя скрещивания чёрно-пёстрого скота с голштинами. При этом чистопородные бычки I группы уступали помесным бычкам II группы по уровню анализируемого показателя на 2,03 \%, а чистопородные бычки-кастраты III группы помесным сверстникам IV группы - на 3,53 \%. В свою очередь чистопородные бычки I группы превосходили по выходу мякоти на 100 кг предубойной живой массы чистопородных бычков-кастратов III группы на 2,54 \%. У помесей преимущество бычков II группы над бычками-кастратами IV группы было менее существенным и находилось на уровне $1,05 \%$.

По соотношению съедобной и несъедобной частей туши наблюдались различия. Чистопородные бычки I группы уступали помесным сверстникам II группы по исследуемому показателю на 3,14 \%. По бычкам-кастратам разница в пользу помесного молодняка IV группы была минимальной и составляла $0,27 \%$. При этом бычки уступали бычкам-кастратам по величине анализируемого показателя. По чистопородному молодняку разница в их пользу составляла 4,00 \%, по помесям $-1,11 \%$.

Известно, что у откормленного молодняка крупного рогатого скота выход мышечной ткани составляет свыше $65 \%$. В этой связи она оказывает существенное влияние на качественные показатели мясной продукции. Полученные нами данные и их анализ свидетельствуют о положительном влиянии скрещивания чёрно-пёстрого скота с голштинами как на выход мышечной ткани, так и на её соотношение с другими тканями туши (табл. 2).

По абсолютной массе мышечной ткани бычки II группы превосходили чистопородных бычков I группы на 19,6 кг (9,97 \%, Р $\leq 0,001)$, а помесные бычки-кастраты - на 14,0 кг $(7,80 \%$, $\mathrm{P} \leq 0,001)$. 
Животноводство и кормопроизводство 2021 T. 104 № 2 / Animal Husbandry and Fodder Production 2021 Vol. 104 Is. 2

Разведение, селекция, генетика

Таблица 2. Выход мышечной ткани туши молодняка подопытных групп, кг $(\mathbf{X} \pm \mathbf{S x})$ / Table 2. The yield of muscle tissue of the young animals of the experimental groups, $\mathrm{kg}(\mathrm{X} \pm \mathrm{Sx})$

\begin{tabular}{|l|c|c|c|c|}
\hline \multicolumn{1}{|c|}{ Показатель / Indicator } & \multicolumn{4}{|c|}{ Группа / Group } \\
\cline { 2 - 6 } & I & II & III & IV \\
\hline Масса мышечной ткани: / Muscle weight: & & & & \\
всего / total & $196,6 \pm 0,72$ & $216,2 \pm 0,88$ & $179,4 \pm 0,64$ & $193,4 \pm 0,79$ \\
на 1 кг костей / per 1 kg of bones & $3,78 \pm 0,33$ & $3,90 \pm 0,38$ & $3,82 \pm 0,31$ & $3,87 \pm 0,34$ \\
$\begin{array}{l}\text { на 100 кг предубойной живой массы / } \\
\text { per 100 kg of pre-slaughter live weight }\end{array}$ & $39,23 \pm 0,76$ & $40,32 \pm 0,80$ & $37,34 \pm 0,58$ & $39,29 \pm 0,67$ \\
$\begin{array}{l}\text { Соотношение мышечной и жировой тка- } \\
\text { ни / The ratio of тиscle to fat tissue }\end{array}$ & $12,44 \pm 0,92$ & $13,68 \pm 0,98$ & $10,55 \pm 0,86$ & $11,24 \pm 0,89$ \\
Соотношение жировой и мышечной тка- & & & & \\
ни / The ratio of fat and muscle tissue & $0,08 \pm 0,01$ & $0,07 \pm 0,01$ & $0,09 \pm 0,01$ & $0,09 \pm 0,01$ \\
\hline
\end{tabular}

Бычки I группы имели также преимущество над чистопородными бычками-кастратами II группы по данному показателю на 17,2 кг (9,59%, P $\leq 0,001)$, по помесям - на 22,8 кг (11,79 \%, P $\leq 0,001)$.

Отмечалось лидирующее положение помесного молодняка и по выходу мышечной ткани туши на 1 кг костей. Так, чистопородные бычки I группы уступали помесным сверстникам II группы по соотношению мышц и костей в туше на 3,17\%, а по бычкам-кастратам разница в пользу помесей IV группы составляла 0,78 \%. При этом отмечалась тенденция превосходства бычковкастратов над бычками по величине анализируемого показателя при статистически недостоверной разнице.

Характерно, что помесный молодняк II и IV групп отличался более высоким уровнем соотношения мышечной и жировой тканей и превосходил по этому признаку чистопородных сверстников на $11,41 \%$ и 6,54 \% соответственно. При этом у бычков величина анализируемого показателя была существенно выше, чем у бычков-кастратов. В то же время бычки-кастраты как чистопородные, так и помесные занимали лидирующее положение по уровню соотношения жировой и мышечной тканей туши.

Важным показателем, во многом характеризующим качество мясного сырья, является сортовой состав съедобной части туши. Именно он определяет направление использования мяса при производстве того или иного вида мясопродуктов.

Анализ полученных данных свидетельствует о положительном влиянии скрещивания скота чёрно-пёстрой породы с голштинами немецкой селекции на сортовой состав мякоти туши (табл. 3).

Помесный молодняк по абсолютной массе съедобной части полутуши превосходил чистопородных аналогов по выходу мяса высшего и первого сорта. Так, бычки I группы уступали сверстникам II группы на 1,62 кг $(0,80 \%, \mathrm{P} \leq 0,05)$, относительной - на 1,08 \%. Бычки-кастраты также уступали помесям IV группы по величине данного показателя на 1,66 кг $(12,79 \%, \mathrm{P} \leq 0,05)$ и $0,69 \%$.

Аналогичные межгрупповые различия отмечались и по выходу мяса первого сорта, где помесные животные II и IV групп имели преимущество над чистопородными сверстниками I и III групп. Отмечено негативное влияние кастрации бычков на выход мяса высшего и первого сорта. Достаточно отметить, что чистопородные и помесные бычки превосходили чистопородных и помесных бычков-кастратов. Так, чистопородные бычки имели преимущество над чистопородными быкамикастратами по абсолютной массе мяса высшего сорта на 2,02 кг (15,56 \%, Р $\leq 0,05)$, первого сорта на 4,96 кг $(10,75 \%, \mathrm{P} \leq 0,01)$, относительной массе - соответственно на $0,91 \%$ и 1,13\%. Аналогичные межгрупповые различия отмечались и у помесного молодняка. 
Таблица 3. Сортовой состав съедобной части полутуши молодняка подопытных групп Table 3. Varietal composition of the edible part of half-carcass of young animals of the experimental groups

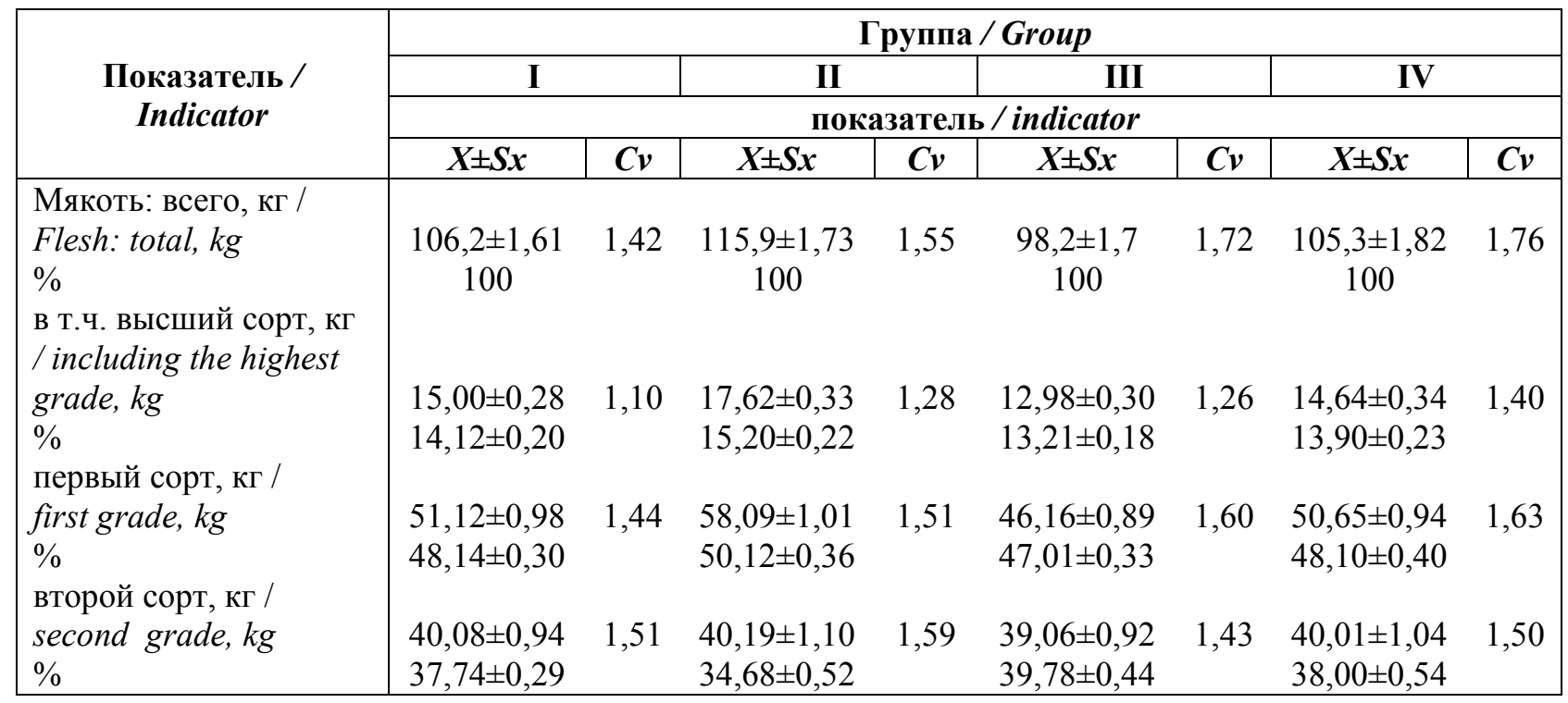

Что касается выхода мяса второго сорта, то между чистопородными и помесными бычками I и II групп и бычками-кастратами III и IV групп существенных межгрупповых различий по её абсолютной массе не отмечалось. По относительной массе лидирующее положение занимал чистопородный молодняк.

Таким образом, мясная продукция, полученная при убое молодняка всех подопытных групп, отличалась высокими качественными показателями.

\section{Обсуждение полученных результатов.}

Известно, что при сочетании генотипа скрещиваемых пород отмечается повышение не только продуктивности помесных животных, но и улучшается качество мясной продукции (Тагиров Х.Х. и Макулова А.Б., 2012; Бактыгалиева А.Т. и Джуламанов К.М., 2017; Kayumov FG et al., 2019).

Это положение нашло подтверждение и при оценке качества мясной продукции, полученной при убое молодняка чёрно-пёстрой породы и её помесей с голштинами. При этом чистопродный молодняк I и III групп уступал помесям II и IV групп по общей массе мякоти туши на 14,219,4 кг (7,23-9,13 \%), индексу мясности - на 0,98-2,45 \%, выходу съедобной части туши на 100 кг предубойной живой массы - на 2,03-3,53 \%, соотношению съедобной и несъедобной частей туши на $0,27-3,14 \%$.

Характерно, что бычки-кастраты II и IV групп, уступая бычкам по абсолютной массе мякоти туши, превосходили их по величине индекса мясности и отличались лучшим соотношением съедобной и несъедобной частей.

Аналогичные межгрупповые различия отмечались по абсолютной массе мышечной ткани и её выходу на 1 кг костей.

Что касается сортового состава съедобной части туши, то отмечено положительное влияние скрещивания чёрно-пёстрого и голштинского скота на этот признак. 


\section{Выводы.}

Скрещивание чёрно-пёстрого скота с голштинами немецкой селекции способствовало повышению качественных показателей мясной продукции помесей. Об этом свидетельствует и повышение абсолютной массы съедобной части туши и мышечной ткани. Кроме того, повышался индекс мясности туши, выход мышечной ткани на 1 кг костей, улучшалось соотношение съедобной и несъедобной частей туши, сортового состава мякоти.

\section{Литература}

1. Бактыгалиева А.Т., Джуламанов К.М. Качественная оценка мяса бычков и кастратов разных генотипов // Вестник мясного скотоводства. 2017. № 1(97). С. 50-56. [Baktygalieva AT, Dzhulamanov KM. Qualitative assessment of meat of bulls and steers of different genotypes. Herald of Beef Cattle Breeding. 2017;1(97):50-56. (In Russ)].

2. Батанов С.Д., Корепанова Л.В. Мясная продуктивность чистопородных и помесных бычков // Зоотехния. 2011. № 6. С. 17-18. [Batanov SD, Korepanova LV. Meat productivity of purebred and crossed bull-calves Zootechniya. 2011;6:17-18. (In Russ)].

3. Герасимов Н.П., Джуламанов К.М., Дубовскова М.П. Основные принципы создания нового внутрипородного типа уральский герефорд // Аграрный вестник Урала. 2010. № 8(74). С. 5153. [Gerasimov N, Dzhulamanov K, Dubovskova M. Basic principles a new intra-breed type Uralskiy Hereford creation. Agrarian Bulletin of the Urals. 2010;8(74):51-53. (In Russ)].

4. Гильмияров Л.А., Тагиров Х.Х., Миронова И.В. Убойные качества молодняка чёрнопёстрой породы и её полукровных помесей с породой обрак // Известия Оренбургского государственного аграрного университета. 2010. № 3(27). С. 88-90. [Gilmiyarov LA, Tagirov KhKh, Mironova IV. Slaughter qualities of black flecked young cattle and their half blood hybrids with Obrack cattle. Izvestia Orenburg State Agrarian University. 2010;3(27):88-90. (In Russ)].

5. Гриценко С.А. Взаимосвязь между показателями роста и развития бычков различного происхождения // Известия Оренбургского государственного аграрного университета. 2012. № 5(37). C. 109-111. [Gritsenko SA. Interconnection between growth and development indices of young bulls of different parentage. Izvestia Orenburg State Agrarian University. 2012;5(37):109-111. (In Russ)].

6. Джуламанов К.М., Бактыгалиева А.Т., Урынбаева Г.Н. Убойные качества молодняка шагатайского типа казахского белоголового скота и его помесей с уральским герефордом // Известия Оренбургского государственного аграрного университета. 2015. № 6(56). C. 130-133. [Dzhulamanov KM, Baktygalieva AT, Urynbaeva GN. Slaughter qualities of young Kazakh white-head cattle of the Shagataisky type and their crosses with Uralsky Herefords. Izvestia Orenburg State Agrarian University. 2015;6(56):130-133. (In Russ)].

7. Есенгалиев А.К., Мазуровский Л.3., Косилов В.И. Эффективность скрещивания казахского белоголового и мандолонгского скота // Молочное и мясное скотоводство. 1993. № 2-3. C. 15-17. [Esengaliev AK, Mazurovskii LZ, Kosilov VI. Effektivnost' skreshchivaniya kazakhskogo belogolovogo i mandolongskogo skota. Molochnoe i myasnoe skotovodstvo. 1993;2-3:15-17. (In Russ)].

8. Качество мяса крупного рогатого скота различных генотипов / А.А. Кочетков, Ф.Г. Каюмов, С.Д. Тюлебаев, А.Б. Карсакбаев // Всё о мясе. 2010. № 2. С. 44-45. [Kochetkov AA, Kayumov FG, Tyulebaev SD, Karsakbaev AB. Quality of meat from cattle of different genotypes. Vse o myase. 2010;2:44-45. (In Russ)].

9. Макаев Ш.А., Жамбулов М.С., Тагузин Р.Ш. Мясная продуктивность и качество мяса казахского белоголового скота разных фенотипов // Известия Оренбургского государственного аграрного университета. 2016. № 1(57). C. 80-82. [Makaev ShA, Zhambulov MS, Taiguzin RSh. Performance and quality of beef obtained from different genotypes of Kazakh white-head cattle. Izvestia Orenburg State Agrarian University. 2016;1(57);80-82. (In Russ)].

10. Миронова И.В., Гильманов Д.Р. Продуктивные качества бычков и кастратов чёрнопёстрой породы и её помесей с породой салерс // Известия Оренбургского аграрного университета. 2013. № 4(42). C. 107-110. [Mironova IV, Gilmanov DR. Productive qualities of black-spotted steers and 
castrates and their hybrids with the Salers. Izvestia Orenburg State Agrarian University. 2013;4(42):107110. (In Russ)].

11. Тюлебаев С.Д. Мясные качества бычков разных генотипов в условиях Южного Урала // Известия Оренбургского государственного аграрного университета. 2011. № 2(30). С. 106-108. [Tyulebaev SD. Beef qualities of steers with different genotypes under the conditions of south urals. Izvestia Orenburg State Agrarian University. 2011;2(30):106-108. (In Russ)].

12. Тагиров Х.Х., Гильмияров Л.А., Миронова И.В. Особенности роста и развития молодняка чёрно-пёстрой породы и её помесей с породой обрак // Известия Оренбургского государственного аграрного университета. 2010. № 3(27). C. 81-83. [Tagirov KhKh, Gilmiyarov LA, Mironova IV. Growth and development peculiarities of young black flecked cattle and their crosses with the Obrack breed. Izvestia Orenburg State Agrarian University. 2010;3(27):81-83. (In Russ)].

13. Тагиров Х.Х., Макулова А.Б. Морфологический и сортовой состав туши молодняка бестужевской породы и её помесей с салерсами // Известия Оренбургского государственного аграрного университета. 2012. № 5(37). C. 117-118. [Tagirov KhKh, Makulova AB. Morphological and varietal carcass composition of Bestuzhev young cattle and their crosses with Salers animals. Izvestia Orenburg State Agrarian University. 2012;5(37):117-118. (In Russ)].

14. Шевхужев А.Ф., Улимбашева Р.А., Улимбашев М.Б. Формирование мясной продуктивности молодняка чёрно-пёстрого и помесного скота при использовании разных технологий выращивания // Известия Тимирязевской сельскохозяйственной академии. 2017. № 3. С. 95-109. [Shevkhuzhev AF, Ulimbasheva RA, Ulimbashev MB. Formation of meat productivity of young animals of black-motley cattle by using different raising production-technological solutions Izvestiya of Timiryazev Agricultural Academy. 2017;3:95-109. (In Russ)].

15. Kayumov FG, Kosilov VI, Gerasimov NP, Bykova OA. The effect of SNP polymorphisms in growth hormone gene on weight and linear growth in crossbred red angus $\mathrm{x}$ kalmyk heifers. Loretts $\mathrm{O}$, Donnik I, Bykova O, Kukhar V, editors. Digital agriculture - development strategy: Proceedings of the International Scientific and Practical Conference (ISPC 2019) Cep. «Advances in Intelligent Systems Research»; March 21-22, 2019. Yekaterinburg, Russian Federation. Paris, France: Atlantis Press. 2019; 167: 325-328 p. doi: 10.2991/ispc-19.2019.73

\section{References}

1. Baktygalieva AT, Dzhulamanov KM. Qualitative assessment of meat of bulls and steers of different genotypes. Herald of Beef Cattle Breeding. 2017;1(97):50-56.

2. Batanov SD, Korepanova LV. Meat productivity of purebred and crossed bull-calves Zootechniya. $2011 ; 6: 17-18$.

3. Gerasimov N, Dzhulamanov K, Dubovskova M. Basic principles a new intra-breed type Uralskiy Hereford creation. Agrarian Bulletin of the Urals. 2010;8(74):51-53.

4. Gilmiyarov LA, Tagirov KhKh, Mironova IV. Slaughter qualities of black flecked young cattle and their half blood hybrids with Obrack cattle. Izvestia Orenburg State Agrarian University. 2010;3(27):88-90.

5. Gritsenko SA. Interconnection between growth and development indices of young bulls of different parentage. Izvestia Orenburg State Agrarian University. 2012;5(37):109-111.

6. Dzhulamanov KM, Baktygalieva AT, Urynbaeva GN. Slaughter qualities of young Kazakh white-head cattle of the Shagataisky type and their crosses with Uralsky Herefords. Izvestia Orenburg State Agrarian University. 2015;6(56):130-133.

7. Esengaliev AK, Mazurovskii LZ, Kosilov VI. The effectiveness of crossing Kazakh whiteheaded and Mandolong cattle. Dairy and Beef Cattle Farming. 1993;2-3:15-17.

8. Kochetkov AA, Kayumov FG, Tyulebaev SD, Karsakbaev AB. Quality of meat from cattle of different genotypes. Everything About Meat. 2010;2:44-45. 
9. Makaev ShA, Zhambulov MS, Taiguzin RSh. Performance and quality of beef obtained from different genotypes of Kazakh white-head cattle. Izvestia Orenburg State Agrarian University. 2016;1(57);80-82.

10. Mironova IV, Gilmanov DR. Productive qualities of black-spotted steers and castrates and their hybrids with the Salers. Izvestia Orenburg State Agrarian University. 2013;4(42):107-110.

11. Tyulebaev SD. Beef qualities of steers with different genotypes under the conditions of south urals. Izvestia Orenburg State Agrarian University. 2011;2(30):106-108.

12. Tagirov KhKh, Gilmiyarov LA, Mironova IV. Growth and development peculiarities of young black flecked cattle and their crosses with the Obrack breed. Izvestia Orenburg State Agrarian University. 2010;3(27):81-83.

13. Tagirov KhKh, Makulova AB. Morphological and varietal carcass composition of Bestuzhev young cattle and their crosses with Salers animals. Izvestia Orenburg State Agrarian University. 2012;5(37):117-118.

14. Shevkhuzhev AF, Ulimbasheva RA, Ulimbashev MB. Formation of meat productivity of young animals of black-motley cattle by using different raising production-technological solutions Izvestiya of Timiryazev Agricultural Academy. 2017;3:95-109.

15. Kayumov FG, Kosilov VI, Gerasimov NP, Bykova OA. The effect of SNP polymorphisms in growth hormone gene on weight and linear growth in crossbred red angus $\mathrm{x}$ kalmyk heifers. Loretts $\mathrm{O}$, Donnik I, Bykova O, Kukhar V, editors. Digital agriculture - development strategy: Proceedings of the International Scientific and Practical Conference (ISPC 2019) Cep. «Advances in Intelligent Systems Research»; March 21-22, 2019. Yekaterinburg, Russian Federation. Paris, France: Atlantis Press. 2019; 167: 325-328 p. doi: 10.2991/ispc-19.2019.73

Косилов Владимир Иванович, доктор сельскохозяйственных наук, профессор, профессор кафедры технологии производства и переработки продукции животноводства, Оренбургский государственный аграрный университет, 460014, г. Оренбург, ул. Челюскинцев, 18, тел.: 8 (3532)77-9328, e-mail: kosilov_vi@mail.ru

Амиршоев Файзулло Сафарович, доктор биологических наук, профессор, вице-президент Таджикской академии сельскохозяйственных наук, 734025, Республика Таджикистан, г. Душанбе, проспект Рудаки 21 “А”, тел.: 810992372310607

Каюмов Фоат Галимович, доктор сельскохозяйственных наук, профессор, руководитель научного направления, заведующий лабораторией новых пород и типов мясного скота, Федеральный научный центр биологических систем и агротехнологий Российской академии наук, 460000 , г. Оренбург, ул. 9 Января, 29, тел.: 8(3532)30-81-76, сот.: 8-987-341-75-80, e-mail: fncbst@mail.ru, nazkalms@mail.ru

Третьякова Рузия Фоатовна, кандидат биологических наук, научный сотрудник отделаразведения мясного скота, Федеральный научный центр биологических систем и агротехнологий Российской академии наук, 460000, г. Оренбург, ул. 9 Января, 29, тел.: 8(3532)30-81-74, e-mail: kserev_1976@mail.ru

Жаймышева Сауле Серекпаевна, кандидат сельскохозяйственных наук, старший научный сотрудник отдела разведения мясного скота, Федеральный научный центр биологических систем и агротехнологий Российской академии наук, 460000, г. Оренбург, ул. 9 Января, 29, тел.: 8(3532)30-81-74, e-mail: fncbst@mail.ru

Поступила в редакцию 20 мая 2021 г.; принята после решения редколлегии 15 июня 2021 г.; опубликована 30 июня 2021 г. / Received: 20 May 2021; Accepted: 15 June 2021;

Published: 30 June 2021 